\title{
Impaired liver regeneration is associated with reduced cyclin B1 in natural killer T cell-deficient mice
}

\author{
Ami Ben Ya'acov ${ }^{1 *+}$, Hadar Meir $^{1 \dagger}$, Lydia Zolotaryova', Yaron $\|^{1}{ }^{1}$ and Eyal Shteyer ${ }^{2}$
}

\begin{abstract}
Background: It has been shown that the proportion of natural killer T cells is markedly elevated during liver regeneration and their activation under different conditions can modulate this process. As natural killer $T$ cells and liver injury are central in liver regeneration, elucidating their role is important.

Methods: The aim of the current study is to explore the role of natural killer T cells in impaired liver regeneration. Concanvalin A was injected 4 days before partial hepatectomy to natural killer T cells- deficient mice or to anti CD1d1-treated mice. Ki-67 and proliferating cell nuclear antigen were used to measure hepatocytes proliferation. Expression of hepatic cyclin B1 and proliferating cell nuclear antigen were evaluated by Western Blot and liver injury was assessed by ALT and histology.

Results: Natural killer T cells- deficient or mice injected with anti CD1d antibodies exhibited reduced liver regeneration. These mice were considerably resistant to ConA-induced liver injury. In the absence of NKT cells hepatic proliferating cell nuclear antigen and cyclin B1 decreased in mice injected with Concanvalin A before partial hepatectomy. This was accompanied with reduced serum interleukin-6 levels.
\end{abstract}

Conclusions: Natural killer T cells play an important role in liver regeneration, which is associated with cyclin B1 and interleukin-6.

Keywords: Liver regeneration, NKT cells, CD1d, CyclinB1, Interleukin-6

\section{Background}

The liver maintains a steady mass balanced by cell gain and cell loss. The tight and regulated mechanisms guaranteeing this steady state are well shown in liver regeneration. The liver is comparatively rich in NKT cells implying of their important role in liver biology [1]. NKT cells are a heterogeneous group of $T$ cells that recognize various lipid antigens presented by the nonclassical MHC class I-like molecule CD1 [2,3].

Accumulating data suggests that the role of NKT cells in the pathogenesis of liver disease is complex and that these cells likely to play different roles especially given

\footnotetext{
* Correspondence: amib@szmc.org.il

tEqual contributors

${ }^{1}$ Liver Unit, Hebrew University-Hadassah Medical Center, Jerusalem, Israel

Full list of author information is available at the end of the article
}

the existence of multiple types of NKT cells, their associated cytokines and the divergence of their foreign and self-antigen lipids $[4,5]$. Several lines of evidence indicate that NKT cells play an important role in triggering and promoting liver regeneration. After partial hepatectomy (PH) the number of NKT was shown to increase and NKT cells were able to mediate cytotoxicity against regenerating hepatocytes $[6,7]$.

Furthermore, activation of NKT cells by the powerful ligand $\alpha$-galactosylceramide has been shown to accelerate liver regeneration after $\mathrm{PH}$ through the TNF and FasL-mediated pathway, and NKT cell-deficient mice $(\mathrm{CD} 1 \mathrm{~d}-/-)$ mice that were not treated with $\alpha$ galactosylceramide showed decreased hepatocyte mitosis after $\mathrm{PH}$ [8]. Likewise, liver regeneration was impaired in mice pre-treated with anti NK1.1 antibodies [9].

Dong and colleagues demonstrated reduced liver regeneration in HBV-tg mice that was associated with 
activated NKT cells and their IFN- $\gamma$ production. They further showed that blockade of CD1d receptor by monoclonal anti CD1d antibody, restored the impaired liver regeneration in these mice [10]. Concanavalin A (Con A), a plant lectin, is widely used to induce in mice rapid, severe and dose-dependent hepatitis and subsequent liver injury $[11,12]$. NKT cells mediate the liver injury in the Con A immune mediated hepatitis model. CD1d-/- mice that lack NKT cells or mice with reduced hepatic NKT cell numbers, exhibit less severe liver pathology than wild-type controls in response to ConA $[13,14]$. The adoptive transfer of hepatic NKT cells to NKT deficient mice restores ConA-mediated hepatitis [14].

The mechanisms by which NKT cells contribute to hepatic inflammation and liver damage in Con A hepatitis have been intensively studied and the regenerative processes were shown to be essential to restore liver function [15], but mechanisms that affect impaired liver regeneration were not always addressed. Wei-Hua et al showed that impaired liver regeneration in mice with hyperhomocysteinemia (HHcy) was also correlated with reduced cyclins and elevated expression of p53 and p21 ${ }^{\text {Cip } 1}$ [16]. In contrast, p21 ${ }^{\text {Cip } 1}$ knockout mice display accelerated hepatocyte proliferation after $\mathrm{PH}$ through $\mathrm{G}_{1}$ phase. In these mice up regulation of Cyclin A, proliferating cell nuclear antigen (PCNA) and Cyclin D1 were observed [17]. In NKT deficient mice impaired liver regeneration was not investigated regarding cell cycle modifiers. NKT cells are thus involved both in mediating the liver injury and in the liver repair process and regeneration. As NKT cells are required to initiate liver injury, the determination of their direct role in this response can be answered only by using selective depletion of NKT cells following the initiation of liver injury that is required to fully elucidate their role in liver regeneration. Another important feature of liver regeneration is the increased production of IL-6 as in other acute liver damages [18] and some studies have also shown that this cytokine plays an important role in protection against liver injury during liver regeneration $[19,20]$.

In the current study we aimed to investigate the effect of pretreatment with a non-lethal dose of ConA on subsequent liver regeneration, regarding NKT cells, thus providing new insight into the roles of Cyclin B1, p21 and IL-6.

\section{Methods}

\section{Animals}

C57Bl/6 male mice (9-10 weeks of age) were purchased from Harlan Laboratories (Jerusalem, Israel). C57BL/6CD1d-/- mice were kindly provided by Luc Van Kaer (Vanderblit University, Nashville, TN, USA). Mice were bred and maintained in specific pathogen-free conditions.
For experiments male mice (9-10 weeks of age) were used. All animals were provided ad labium access to a commercial rodent diet and water. The joint ethics committee (IACUC) of the Hebrew University and Hadassah Medical Center approved the study protocol for animal welfare. The Hebrew University is an AAALAC International accredited institute.

\section{ConA treatment and CD1d targeting}

Wild type or CD1d-/- mice were injected intravenously with either vehicle $(50 \mathrm{mmol} / \mathrm{L}$ Tris, $150 \mathrm{mmol} / \mathrm{L}$ sodium chloride and $4 \mathrm{mmol} / \mathrm{L}$ calcium chloride) or with $10 \mathrm{mg} / \mathrm{kg}$ ConA (MP Biomedicals, Ohio, USA) 4 days before PH. Depletion of NKT cells was carried out by administration of anti-CD1d mAb, which can effectively block CD1d receptor [21]. Control mice were injected isotype control antibody (rat IgG2b). Antibodies (eBioscience) were administered i.v. at a dose of $50 \mu \mathrm{g} /$ mouse $1 \mathrm{~h}$ before ConA injection. Three-four animals were included in each group.

\section{Partial hepatectomy}

All mice, treated or untreated with ConA, were subjected to $70 \% \mathrm{PH}$ under isoflurane anesthesia as described [22] by removal of the median and left lateral lobes. Three hours or $48 \mathrm{~h}$ after PH mice were sacrificed and then serum and tissues were collected.

\section{Evaluation of liver regeneration}

We used Ki-67 to evaluate the proliferation of hepatocytes $48 \mathrm{~h}$ after $\mathrm{PH}$. After sacrifice, formalin-fixed, paraffin-embedded liver samples were cut in 5 - $\mu \mathrm{m}$-thick sections for staining. For immunostaining, sections were deparaffinized, treated in a pressure cooker with citrate buffer and incubated with rabbit anti-mouse Ki-67 (Abcam, Cambridge, UK) diluted 1:100 overnight at $4{ }^{\circ} \mathrm{C}$. After washing the sections were incubated with Mach-3 mouse HRP-polymer (BioCare Medical, Pike Lane, CA, USA), then rinsed in diaminobenzidine (DAB) containing $0.02 \%$ hydrogen peroxide. Finally sections were counterstained with hematoxylin and examined under a light microscope. The number of Ki-67 positive hepatocytes was determined in liver tissues by counting 8 fields at X100 magnification.

\section{Serum ALT measurements}

Blood was collected from all animals by cardiac puncture $48 \mathrm{~h}$ after $\mathrm{PH}$. Levels of serum alanine aminotransferase (ALT) activity were measured by the Reflovet Plus system (Roche Diagnostics, Mannheim, Germany).

\section{SDS PAGE and Western blot analysis}

Whole liver protein extracts were prepared by homogenizing frozen tissue in a buffer containing $50 \mathrm{mM}$ 
Tris- $\mathrm{HCl}(\mathrm{pH} 8.0), 150 \mathrm{mM} \mathrm{NaCl}, 1 \mathrm{mM}$ EDTA, 1\% Triton X-100, protease and phosphatase inhibitors (Sigma, Rehovot, Israel), followed by centrifugation at $4000 \times g$ for $10 \mathrm{~min}$ at $4{ }^{\circ} \mathrm{C}$. Protein concentration was determined by Bradford assay using the Bio-Rad protein assay kit (Bio-Rad Laboratories, Rehovot Israel). In general, 50-60 $\mu \mathrm{g}$ of total liver protein was separated on $10 \%$ sodium dodecyl sulfate-polyacrylamide gel electrophoresis (SDS-PAGE) and transferred to polyvinylidene difluoride membranes (Millipore, Bedford, MA). All membranes were stained with Ponceau $S$ to confirm transfer of protein. After blocking with 5\% nonfat dry milk in Tris-buffered saline- Tween 20, membranes were incubated overnight at $4{ }^{\circ} \mathrm{C}$ with rabbit polyclonal PCNA or p21 or cyclin B1 (Cell Signaling Technology, Beverly, MA, USA). $\beta$-actin (Abcam, Cambridge, UK) was used as loading control. Membranes were then incubated with secondary horseradish peroxidase-conjugated anti-rabbit IgG antibody (Dako A/S, Glosrtup, Denmark). Subsequently, specific bands were visualized using the EZ-ECL chemiluminescence detection kit (Biological Industries, Israel). Images were captured using a lumino-image analyzer (LAS-3000; Fujifilm, Tokyo, Japan) and densitometry was performed using EZQuant-Gel (EZQunat Ltd, Tel Aviv, Israel).

\section{Determination of serum IL-6 levels}

Blood samples were obtained by cardiac puncture of all animals 48 or $3 \mathrm{~h}$ after $\mathrm{PH}$. After $30 \mathrm{~min}$ of coagulation at room temperature, serum was separated and stored at $-80{ }^{\circ} \mathrm{C}$ until assay. Serum levels of IL-6 were determined in various time points by sandwich ELISA using a commercial kit according to the manufacturer's instructions (Quantikine, R\&D Systems, Minneapolis, MN, USA).

\section{Statistics}

Results are expressed as the mean \pm SE. Results were assessed using student $t$ test. $P<0.05$ was considered statistically significant.

\section{Results}

Liver regeneration after $\mathrm{PH}$ is inhibited in the absence of type I NKT cells

To better define the role of NKT cells in liver regeneration, we used ConA to impair this process, examining the effects of ConA-mediated NKT cell activation on liver regeneration. The ConA model represents a wellestablished immune mediated liver disease, which is NKT cell mediated [14]. As hepatocyte damage can lead to compensatory liver regeneration, we aimed to examine how pre-treatment with ConA can affect liver regeneration in regard to NKT cells presence and activity. To address that question two methods were employed. The first was to use CD1d-/- mice that are deficient in NKT cells. Figures $1 \mathrm{a}$ and $\mathrm{c}$ presents the results of liver regeneration measured by Ki-67 in livers of wild type (wt) and in CD1d -/- mice. It can be seen that regardless of ConA administration liver regeneration was dependent on the presence of NKT cells. Four days after ConA administration liver regeneration after $\mathrm{PH}$ in $\mathrm{CD} 1 \mathrm{~d}-/$ - mice was significantly decreased compare to wt mice. The same results were obtained in vehicle (no ConA) experiments. The second method we used was by targeting the CD1d receptor using anti CD1d antibodies. This method to block NKT activity was used by several studies [21, 23]. Fig. $1 \mathrm{~b}$ demonstrates that liver regeneration was significantly reduced in anti CD1d-treated mice, compared to isotype control-treated mice. Hepatocytes injury caused by pre-treatment of ConA did not affect these results. However, in these experiments the level of regeneration was higher in ConA experiments compared to non-ConA experiments. Similar results to Ki-67 staining were obtained with bromodeoxy uridine (BrdU) incorporation and mitotic bodies counts (data not shown).

Figure 1c, upper panel, shows Ki-67 staining of livers taken from wt and CD1d-/- mice $48 \mathrm{~h}$ after $\mathrm{PH}$ that were pre-treated with ConA. Similar histological results were observed in mice that were injected with anti CD1d antibodies and were compared to of isotype control IgG-treated mice (lower panel). Taking together these results demonstrate the importance of type I NKT cells in liver regeneration.

\section{The effect of impaired liver regeneration on cell cycle regulators}

Expression of several cyclins are correlated with hepatocyte proliferation after $\mathrm{PH}[17,24,25]$. In our study we were interested to find whether reduced regeneration was associated with decreased expression of cell cycle modifiers. So we further analyzed how impaired hepatocyte proliferation affected up-stream cell signaling effectors. Wild type and CD1d-/- mice were injected with ConA and 4 days later $70 \% \mathrm{PH}$ was carried out and mice were sacrificed $48 \mathrm{~h}$ later. Total proteins were isolated from livers and subjected to immunoblotting with antibodies against PCNA, cyclin B1 and p21 or $\beta$-actin (Fig. 2a). An analysis of liver cell proliferation by PCNA expression in hepatocytes previously exposed to ConA, revealed 3 -fold less proliferation $48 \mathrm{~h}$ following $\mathrm{PH}$ in CD1d-/- mice compared with wt mice (Fig. 2a, b). The hepatic expression of cyclin B1 and p21 was also considerably lower in CD1d-/- mice; however differences did not reach statistical significance (Fig. 2c and d). Figure 3a demonstrate similar results that were observed in livers from anti IgG and anti CD1d-treated mice. Hepatic expression of PCNA, cyclin B1 and p21 $48 \mathrm{~h}$ following $\mathrm{PH}$ 

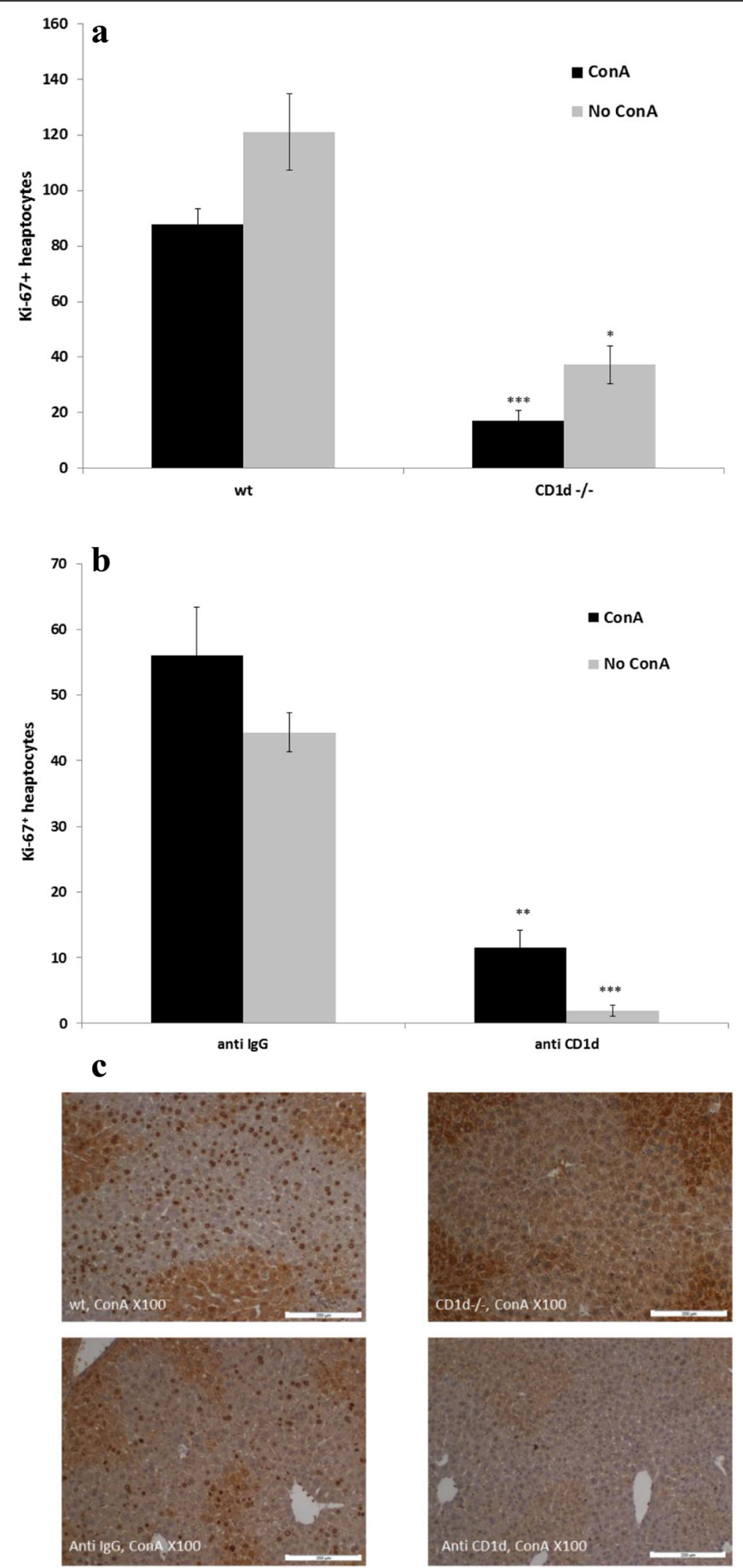

Fig. 1 (See legend on next page.) 
(See figure on previous page.)

Fig. 1 The effect of ConA on liver regeneration in the absence of NKT cells. a ConA was intravenously injected to CD1d-/- or to wild type mice 4 days prior to $70 \% \mathrm{PH}$. In other the experiments vehicle was injected instead of ConA in the same setting. Hepatocellular proliferation was measured by Ki-67 $48 \mathrm{~h}$ after PH. b Anti CD1d or isotype control antibodies were intravenously injected $1 \mathrm{~h}$ before ConA administration 4 days prior to $70 \% \mathrm{PH}$. In the other experiments vehicle was injected instead of ConA in the same setting. Data represent means \pm standard error of a representative experiment. $N=3$ mice or more per condition. All experiments were repeated 3-4 times. In CD1d-/- experiments, ${ }^{*} p<0.005$; ${ }^{* * *} p<0.00005$, relative to wt. In anti CD1d experiments, ${ }^{* *} p<0.0005$; ${ }^{* *} p<0.00005$, relative to isotype control. $\mathbf{c}$ Immunochemistry of Ki-67 positive hepatocytes, $48 \mathrm{~h}$ after PH from ConA-treated liver of wt and CD1d-/- mice (upper panel) and from isotype control and anti CD1d-treated mice (lower panel). Representative photomicrographs at X100 magnification are presented. Scale bars: $200 \mu \mathrm{m}$

in anti CD1d-treated mice that were previously exposed to ConA; was considerably lower than in control-anti IgG treated mice (Fig. 3a). Injection of anti CD1d antibodies caused significant decrease in the expression of these cell cycle regulators (Fig. 3b, c and d).

\section{ALT level after impaired PH is decreased in the absence of type I NKT cells}

Before hepatocytes undergo necrosis after ConA treatment, ALT is released from these cells into blood stream, resulting in abnormally high serum levels of this enzyme. In our study we were interested to examine liver damage after $\mathrm{PH}$ in mice that were challenged by ConA 4 days prior to $\mathrm{PH}$. Figure $4 \mathrm{a}$ shows the results of ALT levels that were measured 48 after $\mathrm{PH}$ in mice that were previously administered ConA. Average ALT levels $48 \mathrm{~h}$ after $\mathrm{PH}$ reached $633 \mathrm{u} / \mathrm{L}$ in wt mice. In contrast, ALT levels in CD1d-/- mice were significantly lower by $50 \%$. In wt and CD1d-/- mice that were not exposed to ConA prior to $\mathrm{PH}, \mathrm{ALT}$ levels were comparable. Similar results were observed $48 \mathrm{~h}$ following $\mathrm{PH}$ in anti IgG and anti CD1d-treated mice that were previously exposed to ConA (Fig. 4b). Average ALT levels reached 678u/L in wt mice, in contrast to average of $154 \mathrm{u} / \mathrm{L}$ of ALT a

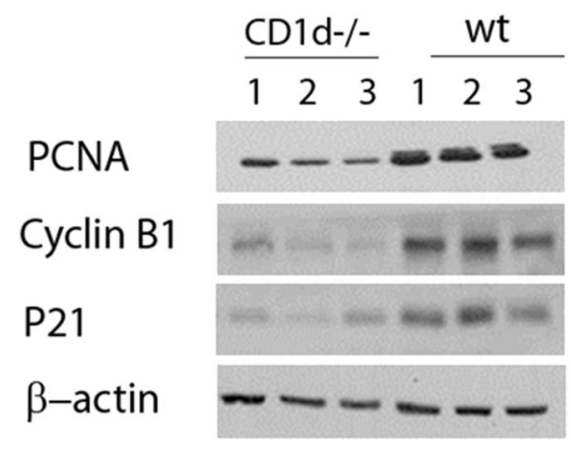

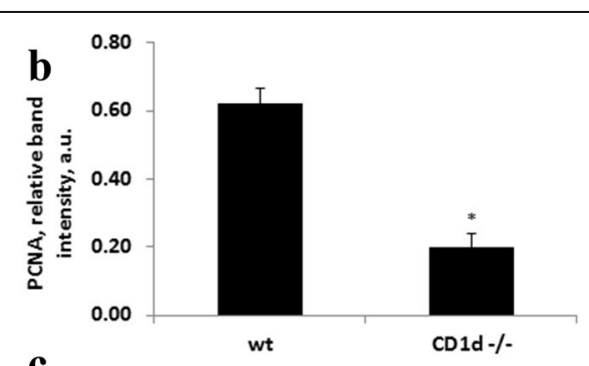
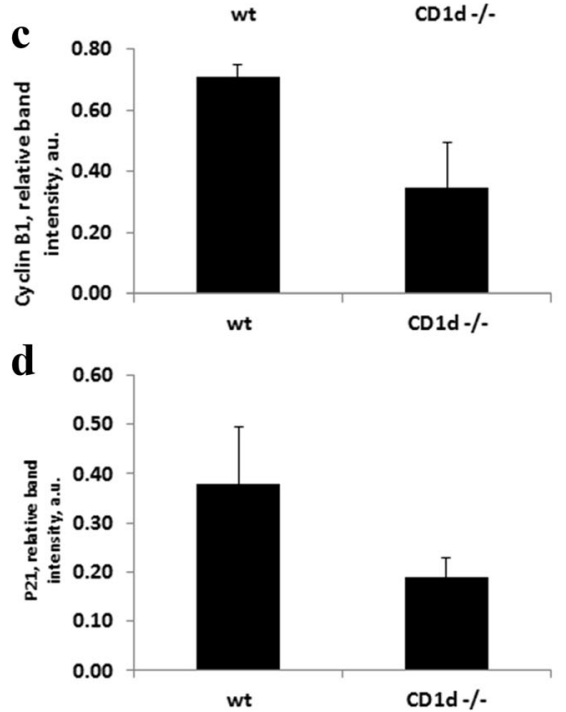

Fig. 2 Expression patterns of hepatic PCNA, P21 and Cyclin B1 during liver regeneration from ConA-challenged wild type and CD1-/- mice. a Western blotting analysis of hepatic remnant lysates, as described in materials and methods, was performed $48 \mathrm{~h}$ after PH using anti PCNA, anti p21 and anti cyclinB1. $\beta$-actin was used as loading control. The illustrated bands are representative of 3 mice per group. b Densitometry of PCNA c Densitometry of Cyclin B1 d Densitometry of p21. Bars are means \pm standard error values of intensity for individual bands that were quantified using EZQuant-Gel densitometry software, and expressed relative to $\beta$-actin, as a measure of protein relative abundance in the different liver samples. * $p<0.02$, relative to wt. a.u.: arbitrary units 


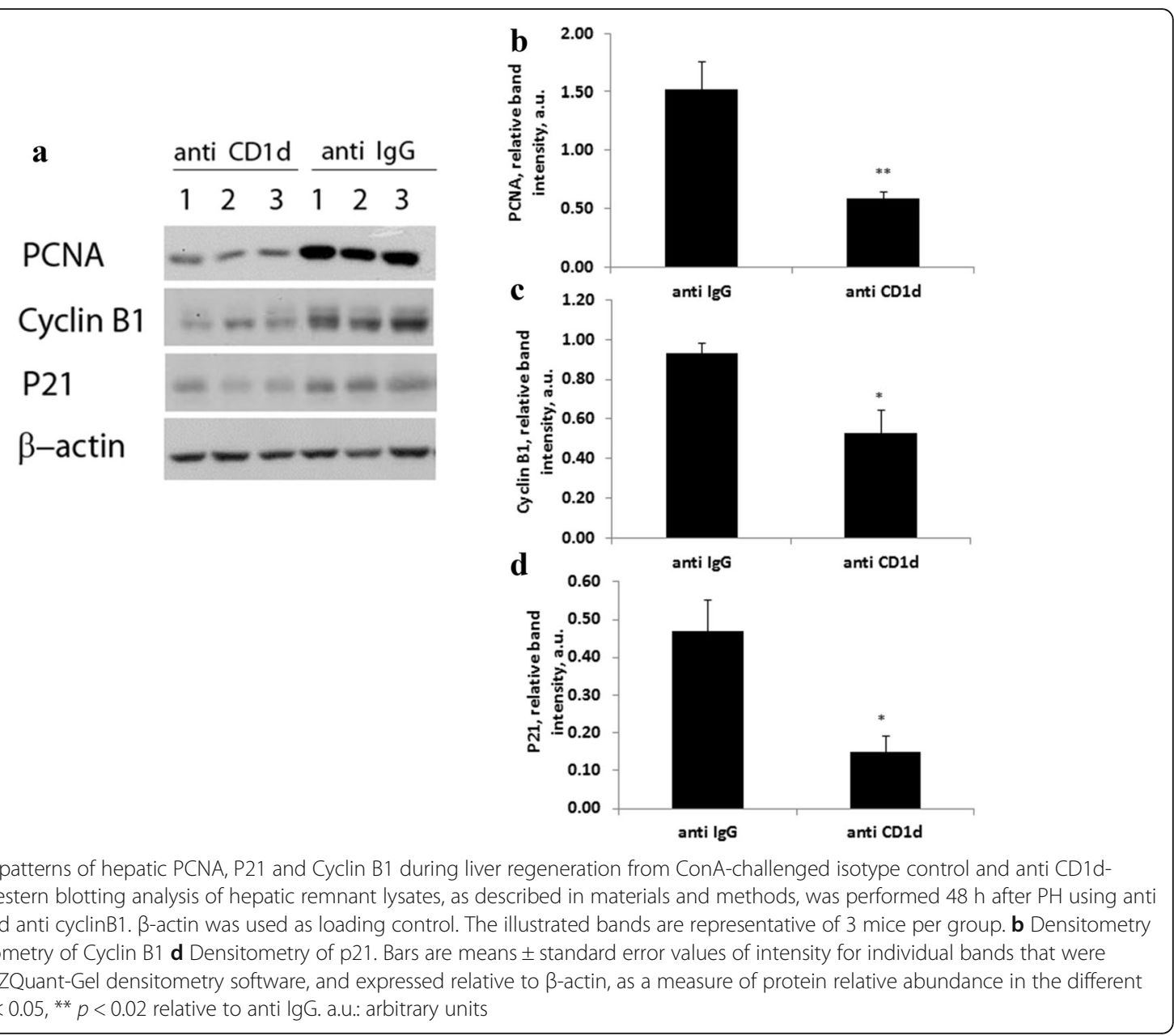

measured in mice injected with anti CD1d antibodies. When mice were not subjected to ConA ALT levels remained low in mice that were treated with isotype control IgG antibodies and even significantly lower in anti CD1d-treated mice. Figure 4c shows that ALT levels measured $3 \mathrm{~h}$ after $\mathrm{PH}$ in wt mice previously exposed to ConA, were significantly elevated compare to CD1d-/mice. However, when mice were not treated with ConA prior to PH, the ALT levels measured in CD1d-/- mice was even lower than in wt mice. Interestingly, the level of ALT enzyme in wt mice previously exposed to ConA, that were measured $3 \mathrm{~h}$ after $\mathrm{PH}$ were similar to those measured $48 \mathrm{~h}$ after $\mathrm{PH}$. Taking together these results demonstrate that ALT rise after $\mathrm{PH}$ in mice treated with ConA is caused by ConA insult and depend in type I NKT cells.

NKT cells affect the secretion of IL- 6 in liver regeneration IL-6 is a key cytokine of liver regeneration that is also elevated during liver disease [26]. Therefore we wanted to determine how the levels of this cytokine were affected in ConA-impaired liver regeneration, in regard to NKT cells. Figure 5 a shows the results of serum IL-6 levels $3 \mathrm{~h}$ after $\mathrm{PH}$, from wt and in CD1d-/- mice that were exposed to ConA. Serum IL-6 levels in CD1d-/- mice were significantly lower in CD1d-/- mice compare to wt mice, $3 \mathrm{~h}$ after $\mathrm{PH}$. However, when mice were not exposed to ConA, similar levels of serum IL-6 levels were recorded in wt and in CD1d-/- mice, indicating that IL-6 levels were affected only in wt mice. Similar results, with or without ConA, were obtained when serum IL-6 levels were measured $48 \mathrm{~h}$ after $\mathrm{PH}$ (Fig. 5b). However, serum IL-6 levels $48 \mathrm{~h}$ after $\mathrm{PH}$ in mice previously exposed to ConA and treated with anti CD1d antibodies was higher than in controls. But when mice were not exposed to ConA prior to $\mathrm{PH}$ the treatment with anti CD1d antibodies lowered serum IL-6 levels by $45 \%$ (Fig. 5c). Taken together, after $\mathrm{PH}$ CD1d-/- mice previously exposed to ConA, exhibited significantly lower IL-6 levels compare to wt mice, these results correlate with reduced liver regeneration in these mice. 

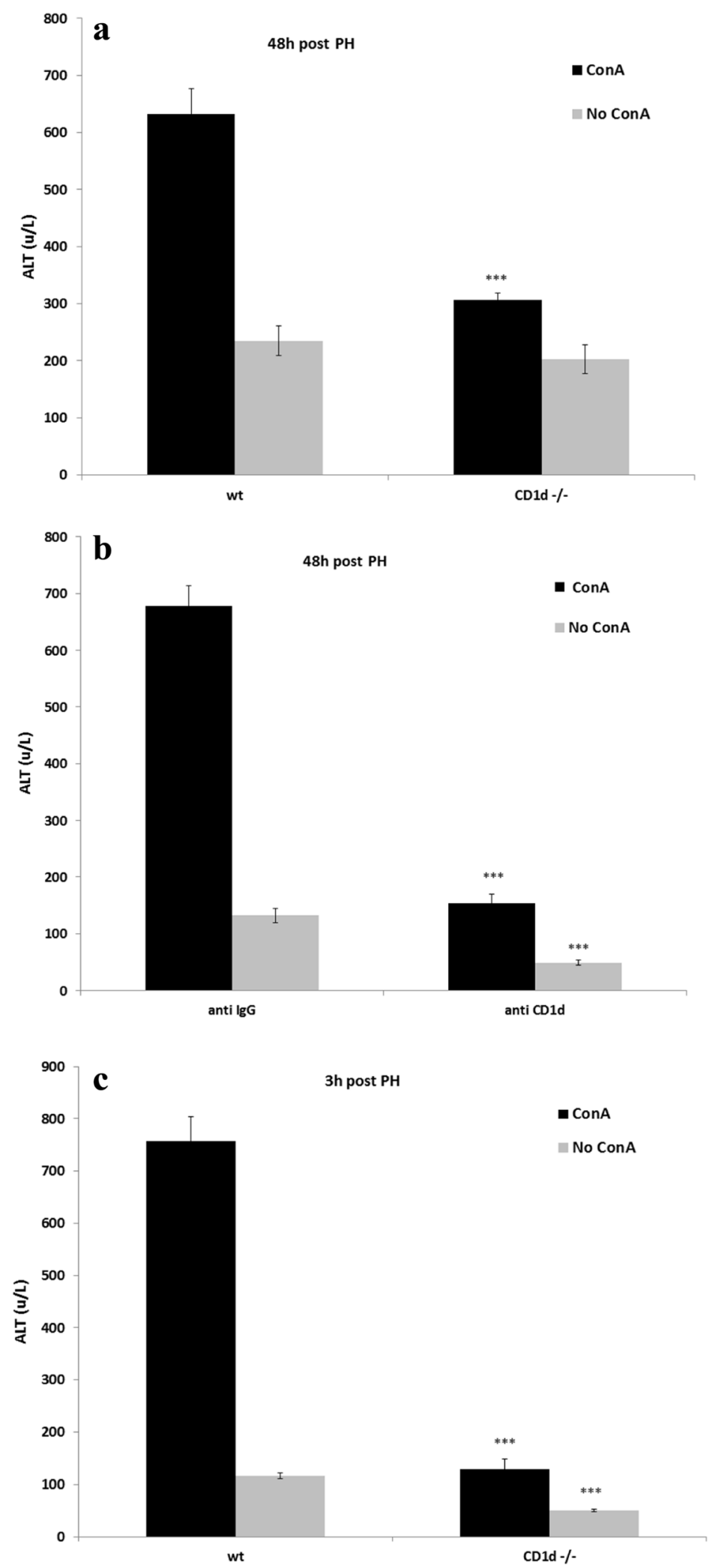

Fig. 4 (See legend on next page.) 
(See figure on previous page.)

Fig. 4 The effect of ConA on liver injury after partial hepatectomy. a ConA was intravenously injected to CD1d-/- or to wild type mice 4 days prior to $70 \% \mathrm{PH}$. In other experiments vehicle was injected instead of ConA in the same setting. Serum ALT levels were measured $48 \mathrm{~h}$ after PH. b Anti CD1d or isotype control antibodies were intravenously injected $1 \mathrm{~h}$ before ConA administration 4 days prior to $70 \% \mathrm{PH}$. In other experiments vehicle was injected instead of ConA in the same setting. Serum ALT levels were measured $48 \mathrm{~h}$ after PH. c As in A, but ALT levels were measured $3 \mathrm{~h}$ after $\mathrm{PH}$. Bars are means \pm standard error values. $N=9$ mice per condition. ${ }^{* *}, p<0.00005$, relative to wild type or lgG-isotype control

\section{Discussion}

Although NKT cells have been shown to be involved in immune mediated diseases [27], asthma [28], antitumor immune responses [29] and inflammatory liver disease $[14,30,31]$, their role in liver regeneration is not fully elucidated. In the current study we aimed to explore one aspect of NKT in liver regeneration.

To investigate the contribution of NKT cells to liver regeneration we first choose to activate NKT cells by ConA. ConA is a plant lectin that induces hepatitis in a well-characterized model of NKT cell-mediated liver disease [32]. Administration of moderate doses of ConA is a well-accepted tool to activate NKT cells. In 8-15 h significant rise in aminotransferases is observed but at later time points, usually after $48 \mathrm{~h}$, liver function is reconstituted [33]. Previous studies have demonstrated the critical contribution of NKT cells to ConA-induced hepatitis by showing that CD1d deficient mice were highly resistant to ConA injection compared to wt mice $[13,14]$. In the current study we showed in CD1d-/- mice and in anti CD1d-treated mice by well-accepted mitotic markers (Ki-67 and PCNA) that hepatocyte proliferation $48 \mathrm{~h}$ after $\mathrm{PH}$ is markedly reduced. In contrast, CD1-/mice on balb.c background have been shown to demonstrate almost normal liver regeneration after $\mathrm{PH}[9,34]$. It is important to stress out that NKT cell numbers are highly variable between mouse strains [35].

Early enhanced regeneration due to ConA pretreatment was attributed to the disappearance of NKT by activation-induced cell death (AICD). Within the current model, ConA induces the rapid activation and depletion of NKT cells, which serve to initiate the injury response. Forty eight hours or more after PH NKT cells can repopulate the liver and are therefore capable of contributing to the regenerative response [36]. Huang et al showed that ConA pretreatment did not accelerate liver regeneration $48 \mathrm{~h}$ after $\mathrm{PH}$, although at earlier time points ConA significantly induced liver regeneration rate. In this study NKT cells disappeared $24 \mathrm{~h}$ after ConA stimulation which was the time point of $\mathrm{PH}$ [15]. We observed that pre-treatment with ConA 4 days before $\mathrm{PH}$ revealed lower hepatic proliferation $48 \mathrm{~h}$ after $\mathrm{PH}$, compared to non-ConA experiments. Similar observations were obtained by Hines and colleagues that showed under the same experiment setting $40 \%$ reduced cell proliferative response after ConA challenge. Four days after ConA administration NKT cells repopulate the hepatic parenchyma [36]. Collectively the negatively regulated role of activated NKT cells diminished along the restoration of NKT cells $48 \mathrm{~h}$ after PH. Tekada et al first demonstrated the critical contribution of NKT cells to ConA-induced hepatitis by showing that CD1d deficient mice were highly resistant to ConA injection compared to wt mice [14]. Nevertheless, the role of NKT cells in liver regeneration is less clear. Impaired liver regeneration by using ConA may provide a tool of exploring their role. We showed significant decreased liver injury in CD1d-/- mice and in anti CD1d-treated mice that were pre-treated with ConA 4 days before $\mathrm{PH}$. High ALT levels $3 \mathrm{~h}$ and $48 \mathrm{~h}$ after $\mathrm{PH}$ are completely attributed to ConA treatment, as without ConA ALT levels in the 2 models were similar to wt or isotype-control mice. When ConA was not applied, targeting CD1d receptor by $\mathrm{mAb}$ was reflected by significantly reduced hepatic proliferation, which may be associated with possible blunting of CD1d receptors on hepatocytes. One cannot rule out that impaired liver regeneration is associated with reduced liver injury caused by the absence of NKT cells. The expression of several cyclins is correlated with hepatocyte cell cycle progression after $\mathrm{PH}[17,24,25]$. Hines and colleagues, who attributed the mechanisms of ConA pre-treatment to the modulation of oval cells, have also studied the effect of impaired liver regeneration on cell cycle. They showed that in ConA pretreated mice the expression of Cyclin D1 was reduced 6 and $24 \mathrm{~h}$ after $\mathrm{PH}$ and of Cyclin E after $48 \mathrm{~h}$. They further showed that phosphorylated Stat3 and IL-6 were reduced in ConA-induced hepatitis, whereas p21 and Smad2 increased. These findings are in agreement with a recent report showing that depletion of NK and NKT cells by anti NK.1.1 antibody resulted in reduced BrdU uptake along with decreased expression of PCNA and Cyclin D, $48 \mathrm{~h}$ after PH [9]. However, under the context of NKT deficiency cell cycle modifiers were not thoroughly investigated. In our study we show decreased expression of hepatic Cyclin B in CD1d-/- mice and in anti- CD1d-treated mice $48 \mathrm{~h}$ after $\mathrm{PH}$. These results were observed in impaired liver regeneration with ConA or without ConA (data not shown). Surprisingly, we found that the levels of p21 in CD1d1-/- mice and in 

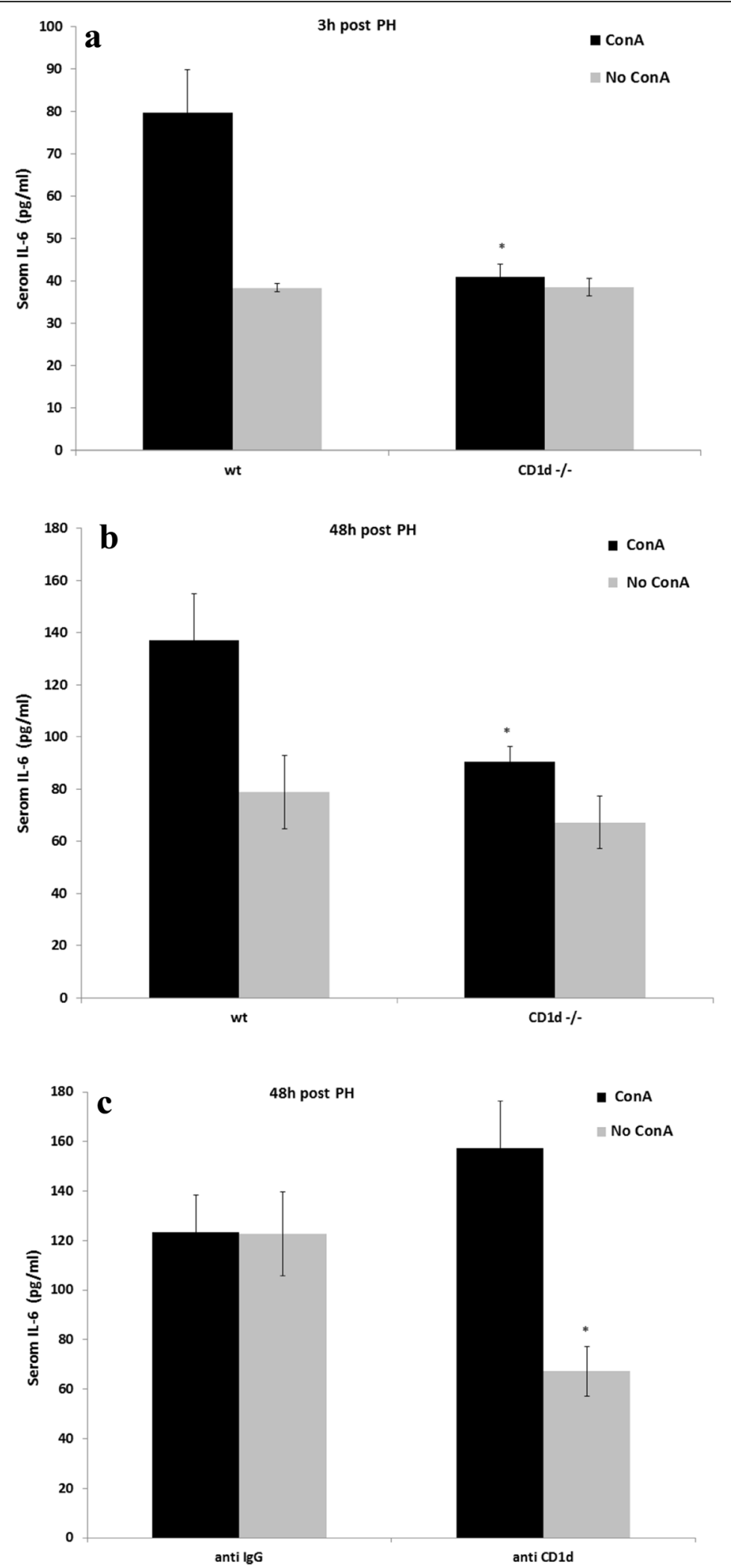

Fig. 5 (See legend on next page.) 
(See figure on previous page.)

Fig. 5 The effect of partial hepatectomy on serum IL-6 secretion after ConA challenge. a ConA was intravenously injected to CD1d-/- or to wild type mice 4 days prior to $70 \% \mathrm{PH}$. In the other experiments vehicle was injected instead of ConA in the same setting. Serum IL-6 levels were measured $3 \mathrm{~h}$ after PH by ELISA (a). b As in A, but IL-6 levels were measured $48 \mathrm{~h}$ after PH. c Anti CD1d or isotype control antibodies were intravenously injected $1 \mathrm{~h}$ before ConA administration 4 days prior to $70 \% \mathrm{PH}$. In the other experiments vehicle was injected instead of ConA in the same setting. Serum IL-6 levels were measured $48 \mathrm{~h}$ after PH. Bars are means \pm standard error values. $N=9$ mice per condition. ${ }^{*} p<0.05$ or ${ }^{*} p<0.01$, relative to wild type or IgG-isotype control, respectively. ${ }^{* *}, p<0.001$, relative to wild type or lgG-isotype control

anti- CD1d treated mice were lower compared to wt and isotype control mice. Although this level expression was measured $48 \mathrm{~h}$ after $\mathrm{PH}$ and not earlier, we cannot rule other mechanistic options. Indeed, p21 was demonstrated as a key inhibitor of $G_{1}$ to $S$ phase progression in hepatocytes [37] and its expression inhibits several genes involved in cell cycle [38], nevertheless, recent discoveries suggest that p21 has additional activities that are unrelated to its function as CDK inhibitors, especially in light of the identification of new targets as well as evidence of Cip/Kip cytoplasmic re-localization [39-41]. However, more investigation is needed to explore the connection between NKT deficiency and p21.

The effect of IL-6 on various forms of liver injury, including ConA and liver regeneration has been well documented. In our study we found that the reduced hepatocyte proliferation in the absence of NKT cells was accompanied with significant decreased levels of serum IL-6 levels 3 and $48 \mathrm{~h}$ after PH. This observation was regardless of ConA challenge. Accordingly, in mice treated with NK1.1 antibody, IL-6 mRNA levels following $\mathrm{PH}$ were blunted significantly [9]. Also in NKT cell-deficient mice, the diminished ConA-induced liver injury was restored by the adoptive transfer of liver mononuclear cells or NKT cells from wild-type mice, but not from IL-6-treated mice [42]. In the study of Sun et al [43] IL-6 prevented ConA-induced hepatitis via the suppression of NKT cells. This effect was partly due to the suppression of Fas ligand expression on NKT cells. Furthermore, adoptive transfer of hepatic mononuclear cells restored ConA-induced liver in jury in anti NK1.1 treated mice. However, adoptive transfer of hepatic mononuclear cells treated with IL-6 failed to restore such injury [43]. Taken together from our investigation, it is apparent that the presence and activity of NKT cells are needed for proper liver regeneration. Impairment of this process by ConA does not change this trend. Further studies are warranted to explore specifically the role of the multiple types of NKT cells. We also show that the impaired Cyclin B1 and p21 expression within the absence of NKT cells or when NKT cells are hampered is in conjugation with reduced liver regeneration and IL- 6 levels.

\section{Conclusions}

NKT cells are needed for liver regeneration. Impairment of Cyclin B1 and p21 expression in the absence of these cells is associated with reduced liver regeneration and serum IL-6.

\section{Abbreviations \\ ALT: Alanine aminotransferase; BrdU: Bromodeoxy uridine; ConA: Concanavalin A; IL-6: Intreleukin-6; iNKT: invariant NKT; MHC: Major histocompatibility complex; NKT: Natural killer T; PCNA: Proliferating cell nuclear antigen; PH: Partial hepatectomy; TNF: Tumor necrosis factor}

\section{Acknowledgements}

Not applicable

Funding

This work was supported by internal grants (Y.I and E.S).

\section{Availability of data and materials}

The datasets used and analyzed during the current study are available from the corresponding author on reasonable request.

\section{Authors' contributions}

All contributing authors have agreed to the submission of this manuscript for publication. HM and LZ performed the experiments and interpreted the results. $A B Y$ designed the experiments, analyzed the data and wrote the manuscript. ES and $\mathrm{YI}$ participated in the design and interpretation of the results, as well as in the critical review of the paper. All authors have read and approved the final version of this manuscript.

\section{Competing interests}

The authors declare that they have no competing interests.

\section{Consent for publication}

Not applicable

\section{Ethics approval and consent to participate}

All animal experiments were performed according to the guidelines of the joint ethics committee (IACUC) of the Hebrew University and Hadassah Medical Center which approved the study protocol. The Hebrew University is an AAALAC International accredited institute.

\section{Publisher's Note}

Springer Nature remains neutral with regard to jurisdictional claims in published maps and institutional affiliations.

\section{Author details \\ ${ }^{1}$ Liver Unit, Hebrew University-Hadassah Medical Center, Jerusalem, Israel. ${ }^{2}$ Department of Pediatrics, Hebrew University-Hadassah Medical Center,} Jerusalem, Israel.

Received: 11 October 2016 Accepted: 10 March 2017 Published online: 23 March 2017

\section{References}

1. Dong Z, Wei $H$, Sun $R$, Tian Z. The roles of innate immune cells in liver injury and regeneration. Cell Mol Immunol. 2007;4(4):241-52. 
2. Godfrey DI, MacDonald HR, Kronenberg M, Smyth MJ, Van Kaer L. NKT cells: what's in a name? Nat Rev Immunol. 2004;4(3):231-7.

3. Brennan PJ, Brigl M, Brenner MB. Invariant natural killer T cells: an innate activation scheme linked to diverse effector functions. Nat Rev Immunol. 2013;13(2):101-17.

4. Santodomingo-Garzon T, Swain MG. Role of NKT cells in autoimmune liver disease. Autoimmun Rev. 2011;10(12):793-800.

5. Duwaerts CC, Gregory SH. Targeting the diverse immunological functions expressed by hepatic NKT cells. Expert Opin Ther Targets. 2011;15(8):973-88.

6. Matsushita T, Ando K, Kimura K, Ohnishi H, Imawari M, Muto Y, Moriwaki H. IL-12 induces specific cytotoxicity against regenerating hepatocytes in vivo. Int Immunol. 1999;11(5):657-65.

7. Minagawa M, Oya H, Yamamoto S, Shimizu T, Bannai M, Kawamura H, Hatakeyama K, Abo T. Intensive expansion of natural killer T cells in the early phase of hepatocyte regeneration after partial hepatectomy in mice and its association with sympathetic nerve activation. Hepatology. 2000;31(4):907-15.

8. Nakashima H, Inui T, Habu Y, Kinoshita M, Nagao S, Kawaguchi A, Miura S, Shinomiya N, Yagita H, Seki S. Activation of mouse natural killer T cells accelerates liver regeneration after partial hepatectomy. Gastroenterology. 2006;131(5):1573-83.

9. Hosoya S, Ikejima K, Takeda K, Arai K, Ishikawa S, Yamagata H, Aoyama T, Kon K, Yamashina S, Watanabe S. Innate immune responses involving natural killer and natural killer T cells promote liver regeneration after partial hepatectomy in mice. Am J Physiol Gastrointest Liver Physiol. 2013;304(3):G293-9.

10. Dong Z, Zhang J, Sun R, Wei H, Tian Z. Impairment of liver regeneration correlates with activated hepatic NKT cells in HBV transgenic mice. Hepatology. 2007:45(6):1400-12.

11. Tiegs G, Hentschel J, Wendel A. A T cell-dependent experimental liver injury in mice inducible by concanavalin A. J Clin Invest. 1992;90(1):196-203.

12. Gantner F, Leist M, Lohse AW, Germann PG, Tiegs G. Concanavalin Ainduced T-cell-mediated hepatic injury in mice: the role of tumor necrosis factor. Hepatology. 1995;21(1):190-8.

13. Geissmann F, Cameron TO, Sidobre S, Manlongat N, Kronenberg M, Briskin MJ, Dustin ML, Littman DR. Intravascular immune surveillance by CXCR6+ NKT cells patrolling liver sinusoids. PLoS Biol. 2005;3(4):e113.

14. Takeda K, Hayakawa Y, Van Kaer L, Matsuda H, Yagita H, Okumura K. Critical contribution of liver natural killer T cells to a murine model of hepatitis. Proc Natl Acad Sci U S A. 2000;97(10):5498-503.

15. Huang W, Dong Z, Wei H, Ding C, Sun R, Tian Z. Selective elimination of hepatic natural killer $T$ cells with concanavalin A improves liver regeneration in mice. Liver Int. 2006;26(3):339-45.

16. Liu WH, Zhao YS, Gao SY, Li SD, Cao J, Zhang KQ, Zou CG. Hepatocyte proliferation during liver regeneration is impaired in mice with methionine diet-induced hyperhomocysteinemia. Am J Pathol. 2010;177(5):2357-65.

17. Albrecht JH, Poon RY, Ahonen CL, Rieland BM, Deng C, Crary GS. Involvement of p21 and p27 in the regulation of CDK activity and cell cycle progression in the regenerating liver. Oncogene. 1998;16(16):2141-50.

18. Galun $\mathrm{E}$, Axelrod JH. The role of cytokines in liver failure and regeneration: potential new molecular therapies. Biochim Biophys Acta. 2002;1592(3):345-58.

19. Wuestefeld T, Klein C, Streetz KL, Betz U, Lauber J, Buer J, Manns MP, Muller W, Trautwein C. Interleukin-6/glycoprotein 130-dependent pathways are protective during liver regeneration. J Biol Chem. 2003:278(13):11281-8.

20. Blindenbacher A, Wang X, Langer I, Savino R, Terracciano L, Heim MH. Interleukin 6 is important for survival after partial hepatectomy in mice. Hepatology. 2003;38(3):674-82.

21. Faunce DE, Gamelli RL, Choudhry MA, Kovacs EJ. A role for CD1drestricted NKT cells in injury-associated T cell suppression. J Leukoc Biol. 2003:73(6):747-55

22. Shteyer E, Liao Y, Muglia L, Hruz PW, Rudnick DA. Disruption of hepatic adipogenesis is associated with impaired liver regeneration in mice. Hepatology. 2004;40(6):1322-32.

23. Kinjo Y, Wu D, Kim G, Xing GW, Poles MA, Ho DD, Tsuji M, Kawahara K, Wong $\mathrm{CH}$, Kronenberg M. Recognition of bacterial glycosphingolipids by natural killer T cells. Nature. 2005;434(7032):520-5.

24. Factor VM, Jensen MR, Thorgeirsson SS. Coexpression of C-myc and transforming growth factor alfa in the liver promotes early replicative senescence and diminishes regenerative capacity after partial hepatectomy in transgenic mice. Hepatology. 1997;26(6):1434-43.
25. Jaumot M, Estanyol JM, Serratosa J, Agell N, Bachs O. Activation of cdk4 and cdk2 during rat liver regeneration is associated with intranuclear rearrangements of cyclin-cdk complexes. Hepatology. 1999;29(2):385-95.

26. Streetz KL, Luedde T, Manns MP, Trautwein C. Interleukin 6 and liver regeneration. Gut. 2000;47(2):309-12.

27. Novak J, Lehuen A. Mechanism of regulation of autoimmunity by iNKT cells. Cytokine. 2011;53(3):263-70.

28. Matangkasombut P, Marigowda G, Ervine A, Idris L, Pichavant M, Kim HY, Yasumi T, Wilson SB, DeKruyff RH, Faul JL, et al. Natural killer T cells in the lungs of patients with asthma. J Allergy Clin Immunol. 2009;123(5):1181-5.

29. Metelitsa LS. Anti-tumor potential of type-I NKT cells against CD1d-positive and CD1d-negative tumors in humans. Clin Immunol. 2011;140(2):119-29.

30. Kaneko Y, Harada M, Kawano T, Yamashita M, Shibata Y, Gejyo F, Nakayama T, Taniguchi M. Augmentation of Valpha14 NKT cell-mediated cytotoxicity by interleukin 4 in an autocrine mechanism resulting in the development of concanavalin A-induced hepatitis. J Exp Med. 2000;191(1):105-14.

31. Diao H, Kon S, Iwabuchi K, Kimura C, Morimoto J, Ito D, Segawa T, Maeda M, Hamuro J, Nakayama T, et al. Osteopontin as a mediator of NKT cell function in T cell-mediated liver diseases. Immunity. 2004;21 (4):539-50.

32. Wang HX, Liu M, Weng SY, Li JJ, Xie C, He HL, Guan W, Yuan YS, Gao J. Immune mechanisms of Concanavalin A model of autoimmune hepatitis. World J Gastroenterol. 2012:18(2):119-25.

33. Sun K, Xie X, Xie J, Jiao S, Chen X, Zhao X, Wang X, Wei L. Cell-based therapy for acute and chronic liver failures: distinct diseases, different choices. Sci Rep. 2014;4:6494.

34. Sun $R$, Gao B. Negative regulation of liver regeneration by innate immunity (natural killer cells/interferon-gamma). Gastroenterology. 2004;127(5):1525-39.

35. Poulton LD, Smyth MJ, Hawke CG, Silveira P, Shepherd D, Naidenko OV, Godfrey DI, Baxter AG. Cytometric and functional analyses of NK and NKT cell deficiencies in NOD mice. Int Immunol. 2001;13(7):887-96.

36. Hines IN, Kremer M, Isayama F, Perry AW, Milton RJ, Black AL, Byrd CL, Wheeler MD. Impaired liver regeneration and increased oval cell numbers following T cell-mediated hepatitis. Hepatology. 2007;46(1):229-41.

37. Wu H, Wade M, Krall L, Grisham J, Xiong Y, Van Dyke T. Targeted in vivo expression of the cyclin-dependent kinase inhibitor p21 halts hepatocyte cell-cycle progression, postnatal liver development and regeneration. Genes Dev. 1996;10(3):245-60.

38. Chang BD, Watanabe K, Broude EV, Fang J, Poole JC, Kalinichenko TV, Roninson IB. Effects of p21Waf1/Cip1/Sdi1 on cellular gene expression: implications for carcinogenesis, senescence, and age-related diseases. Proc Natl Acad Sci U S A. 2000;97(8):4291-6.

39. Coqueret $\mathrm{O}$. New roles for p21 and p27 cell-cycle inhibitors: a function for each cell compartment? Trends Cell Biol. 2003;13(2):65-70.

40. Barre B, Avril S, Coqueret O. Opposite regulation of myc and p21waf1 transcription by STAT3 proteins. J Biol Chem. 2003;278(5):2990-6.

41. Soria G, Gottifredi V. PCNA-coupled p21 degradation after DNA damage: the exception that confirms the rule? DNA Repair (Amst). 2010;9(4):358-64.

42. Geller DA, Tsung A, Marsh JW, Dvorchik I, Gamblin TC, Carr Bl. Outcome of 1000 liver cancer patients evaluated at the UPMC Liver Cancer Center. J Gastrointest Surg. 2006;10(1):63-8.

43. Sun R, Tian Z, Kulkarni S, Gao B. IL-6 prevents T cell-mediated hepatitis via inhibition of NKT cells in CD4+ T cell- and STAT3-dependent manners. J Immunol. 2004;172(9):5648-55.

\section{Submit your next manuscript to BioMed Central and we will help you at every step:}

- We accept pre-submission inquiries

- Our selector tool helps you to find the most relevant journal

- We provide round the clock customer support

- Convenient online submission

- Thorough peer review

- Inclusion in PubMed and all major indexing services

- Maximum visibility for your research

Submit your manuscript at www.biomedcentral.com/submit
Biomed Central 